\title{
No Joking Matter: Discursive Struggle in the Canadian Refugee System
}

\author{
Cynthia Hardy \\ Department of Management \\ Faculty of Economics and Commerce \\ University of Melbourne \\ Parkville 3052, Victoria, Australia \\ E-mail: c.hardy@ecomfac.unimelb.edu.au \\ and \\ Nelson Phillips \\ Faculty of Management \\ McGill University \\ 1001 Sherbrooke West \\ Montreal, Quebec \\ Tel: (514) 398-3602 \\ Fax: (514) 398-3876 \\ E-mail: phillips@management.mcgill.ca
}

Key words: discourse analysis, institution theory, institution field, refugee, power, cartoons

Published in Organization Studies, 20(1), 1-24, 1999 


\section{No Joking Matter: \\ Discursive Struggle in the Canadian Refugee System}

Organizations often engage in discursive struggle as they attempt to shape and manage the institutional field of which they are a part. This struggle is influenced by broader discourses that exist at the societal level and enable and constrain discursive activity within the institutional field. We investigate this relationship by combining a study of political cartoons, as indicators of the broader societal discourse around immigration, with a case study of the Canadian refugee system, a complex institutional field. Our analysis reveals the complex intertextual and interdiscursive relations that characterize and surround institutional fields, and shows how discursive struggle in the refugee determination system is shaped by, and shapes, broader societal discourses. 


\section{Introduction}

In this paper, we develop a framework for understanding the inter-relationship between discursive activity at the level of an institutional field and the societal discourses that surround the field. While work focusing on discourse and language is becoming increasingly common in the organizational analysis literature (e.g., Huff 1990; Mumby and Stohl 1991; Hatch and Ehrlich 1993; Boje 1995; Mauws and Phillips 1995; O’Connor 1995; Phillips 1995; Watson 1995; Ford and Ford 1996; Garsten and Grey 1997; Hamilton 1997; Keenoy et al. 1997; Litvin 1997; Phillips and Hardy 1997), the importance of the broader societal context as a source of discursive resources for organizational and interorganizational discursive activity has received far less attention (Keenoy et al. 1997). Consequently, while we are learning more about discursive activity within and between organizations, the role played by broader discourses in enabling and constraining this activity is less well understood.

In order to explore these relationships, we draw on a study of the Canadian refugee system. Specifically, we examine the link between the broader discourse of immigration — as represented in the form of cartoons - and the discursive activities of members of this particular institutional field. As we noted in an earlier paper (Phillips and Hardy 1997), refugees are constituted through the discursive activities of different organizations in this complex institutional field. Refugees are not, however, produced solely by the discourse that takes place within the refugee system; they are also produced by much broader discourses that occur at a societal level, and that act as a resource and a constraint for actors within the field. In this regard, this paper further develops the themes of our earlier paper to provide a greater understanding of the discursive context within which individual strategies occur.

The remainder of this paper is structured in five sections. We first provide an overview of discourse analysis and discuss the link between discourse in a particular institutional field and discourses at the societal level. We then introduce the example of the Canadian refugee system and show how broader societal discourses of human rights, sovereignty, paternalism and empowerment form the foundation of the discursive struggles within it. Third, we analyze a sample of cartoons to show how the societal immigration discourse helps to constitute refugees. Fourth, we discuss how the societal immigration discourse constrains and facilitates the activities of particular members of the institutional field. Finally, we examine the implications of this study for research and practice.

\section{Institutional Fields and Discursive Production}

We define a discourse as a system of texts that brings an object into being (Parker 1992). Discourse is therefore the foundation of the process of social construction upon which social reality depends (Berger and Luckmann 1967). Discourse does not simply mirror 'reality', but brings into being 'situations, objects of knowledge, and the social identities of and relations between people and groups of people’ (Fairclough and Wodak 1997: 258). By extension, discourse analysis is the structured investigation of these systems of texts and the concepts, objects, and subjects that they constitute (Fairclough 1992; van Dijk 1997c). Methods of social scientific investigation that can be referred to as discourse analysis therefore include a wide variety of methods (Keenoy et al. 1997: 148-149; van Dijk 1997a,b) from semiotics to deconstructionism that share two fundamental characteristics: they are interested in the constructive effects of texts and they are necessarily interpretive. 
The specific approach we adopt in this paper is generally referred to as critical discourse analysis. It focuses on the role of discursive activity in constituting and sustaining power relations:

Discursive practices may have major ideological effects: that is, they can help produce and reproduce unequal power relations between (for instance) social classes, women and men, and ethnic/cultural majorities and minorities through the ways in which they represent things and position people. ... Both the ideological loading of particular ways of using language and the relations of power which underlie them are often unclear to people. CDA aims to make more visible these opaque aspects of discourse. (Fairclough and Wodak 1997: 258)

The ability of actors to manage discursive processes to their advantage is therefore our concern in this paper. We attempt to analyze 'dialogical struggle (or struggles) as reflected in the privileging of a particular discourse and the marginalization of others' (Keenoy et al. 1997: 150; Mumby and Stohl 1991). But what form, exactly, do such struggles take and how are they influenced by the constructive effects of discursive activity? Drawing on the work of Fairclough (1992; also see Taylor 1986: 36), we focus on how discursive activity structures the social space within which actors act through the constitution of concepts, objects, and subject positions.

\section{Concepts}

Discourse produces sets of concepts - ideas, categories, relationships, and theories through which we understand the world and relate to one another — that are more or less contested and which are culturally and historically situated (Harré 1979). Concepts are what Fairclough and Wodak (1997: 258) refer to as 'objects of knowledge' or what Taylor (1985: 36) calls 'intersubjective meanings'. They depend on the ongoing construction of texts for meaning and may, therefore, change dramatically over time and from one situation to another as texts are produced, disseminated, and interpreted by actors in a social situation. For example, the concept of a refugee was originally defined by the United Nations, but continues to be negotiated and changed as new texts are produced and added to the existing discourse (Phillips and Hardy 1997). Discursive activity often aims to transform a concept in order to change individual understandings of the world and, hence, how social relations are accomplished.

\section{Objects}

Some concepts exist only in the expressive order, while others may be attached to a material referent to produce an object. In this way, discourses make the material world meaningful. Objects are part of the practical order, which does not mean that they pre-exist as objects in some way that is revealed by the discourse. Rather, it means that some concepts are discursively attached to particular parts of an ambiguous material world; a world that has an ontological status and a physical existence apart from our experience of them (e.g., Laclau and Mouffe 1987). The concept of a refugee exists in our minds, but the refugee who appears before an immigration official is a physical entity, made sensible and given meaning by the concept of refugee (and in a very different way than, for example, the concept of an illegal immigrant). Our distinction between concepts and objects parallels Rorty's distinction between different kinds of objects. Rorty (1991: 106) differentiates between objects whose 'causal relations are either terribly indirect or simply non-existent' (which we call concepts) and objects 'that cause you to have beliefs about them by fairly direct causal means' because they relate to a physical referent (which we refer to as objects).

The role of discourse in constituting objects thus often revolves around using different 
concepts to produce different objects (Hardy 1997). For example, if the concept of a 'political' refugee is applied to a particular individual, his or her rights to asylum are placed centre-stage. The concept of an 'economic' refugee, on the other hand, highlights the importance of measures to limit access and to deter or detain the individual. In other words, as concepts change, new objects are produced and, equally importantly, very different practices are invoked to deal with the individual (see Phillips and Hardy 1997).

\section{Subject Positions}

Subject positions are also constructed in discourse (Fairclough 1992: 64; Parker 1992: 68). When individuals participate in particular discourses, they do not do so as fully formed subjects (Gergen 1991; Rorty 1989). Instead, speaking within a discourse requires the actor to take up one of a limited number of available subject positions. In other words, statements within a discourse are not produced by independently acting subjects but, rather, help to position and to produce the subject in the context of the particular discourse (Foucault 1972). Thus discourse shapes the subjective experience and the actions of those participating in it and, in so doing, helps to produce their subjectivities.

The various receivers and interpreters of a particular text are produced in a similar way (e.g., Althusser 1971; Ochs 1997). As Condor and Antaki (1997: 338) note:

[Parcels of language are not] simply posted from one speaker to another but are somehow packed together jointly. For Mead, it was a matter of collusion between the speaker and the audience; and for Bakhtin, a matter of infiltration into one speaker's utterances of the interests and perspectives of the other. In both cases, the utterance - and the 'cognition' from whence it came — was meaningless without an appreciation of its joint, or multiple authorship.

So, for example, not only are refugees produced by discourses about refugees, so too are immigration officers, asylum officers, lawyers, and politicians, not to mention illegal aliens and economic migrants (Phillips and Hardy 1997). These different subject positions have different rights to speak (Laclau and Mouffe 1987; Parker 1982). In other words, some individuals, by virtue of their position in the discourse, will warrant a louder voice than others (Potter and Wetherell 1987), while others may warrant no voice at all.

\section{Discourse and Institutional Fields}

In organizational discourse analysis 'the communicative practices of members are examined for the ways that they contribute to the ongoing (and sometimes rather precarious) process of organizing' (Mumby and Clair 1997: 181). From the perspective of critical organizational discourse analysis (Mumby and Clair 1997: 183), we are particularly interested in political acts by organizational members as they engage in discursive activity to re-constitute concepts, objects and subject positions and, thereby, change the way other actors respond in an organizational context (e.g., Fairclough 1992; Parker 1992; Mumby forthcoming).

Not all of this activity occurs within the confines of an individual organization, however. Some of it takes place in the institutional fields that surround organizations. An institutional field is a social space encompassing those organizations that, in the aggregate, constitute a recognized area of institutional life' (DiMaggio and Powell 1983: 148; also see Warren et al. 1974; Lawrence 1997). It is delimited by a particular distribution of institutionalized rules and resources, cultural and structural equivalence, and network interconnections (e.g., DiMaggio and Powell 1983; Hinings and Greenwood 1988; Lawrence 1997; Scott 1995). 
Institutional fields develop through a process of structuration, where patterns of social action produce and reproduce the rules and resources that constitute the field (Giddens 1984; Whittington 1992).

The process of institutional definition, or 'structuration', consists of four parts: an increase in the extent of interaction among organizations in the field; the emergence of sharply defined interorganizational structures of domination and patterns of coalition; an increase in the information load with which organizations in a field must contend; and the development of a mutual awareness among participants in a set of organization that they are involved in a common enterprise (DiMaggio and Powell 1983: 148).

This process is one of social construction growing out of discursive activity. Through repeated interactions, groups of organizations develop common understandings and practices that form the rules and resources that define the field. At the same time, these rules and resources shape the ongoing patterns of interaction from which they are produced (also see Trist 1983; Gray 1989; Hardy 1994a on the social construction of interorganizational domains).

Structuration processes produce patterns of institutionalization that advantage some members at the expense of others (Warren et al 1974; Hardy and Phillips forthcoming). The institutionalization of practices and structures embody sets of power relations (Clegg 1989) that are deeply embedded in the institutionalized practices and taken-for-granted rules that shape institutional action. This form of power is best understood as 'systemic.' It 'lies in the power of the system in the unconscious acceptance of the values, traditions, cultures and structures of a given institution or society' (Hardy 1994b: 230). This form of power affects the strategic opportunities of members of the institutional field but is not the straightforward or direct result of discrete acts of agency. Rather it is the result of complex discursive struggles between members of an institutional field as each tries to influence the way in which it is defined (Phillips and Hardy 1997; Hardy and Phillips forthcoming).

\section{Societal-Level Discourse}

Institutional fields are characterized by the institutionalized practices and understandings that link together the organizations and individuals that comprise the field. These institutionalized practices and understandings are the product of discourse and the institutional field can be thought of as being produced by, and simultaneously producing, discourse. We cannot, however, fully understand the dynamics of an institutional field by looking at the discursive activity in that field alone. Instead, we must also examine how broader discourses, which are constituted by complex macro-societal processes and which evolve over longer periods of time, affect a particular institutional field. We suggest, in fact, that actors in a particular institutional field draw strategically on broader discourses in ways that contribute to the production, modification and dissemination of field-specific discourse.

These interactions are complex. Discourse at the societal level occurs through a broad range of mass media, including television, movies, radio, newspapers and the Internet, which provide channels for the production and distribution of texts to a wide and diverse audience.

Discourses are always connected to other discourses which were produced earlier, as well as those which are produced synchronically and subsequently. In this respect, we include intertextuality as well as sociocultural knowledge within our concept of context (Fairclough and Wodak 1997: 277). 
Many different actors participate in this level of discourse and the level of interdiscursivity the amount that different discourses draw on each other — is high. Accordingly, discourses within an institutional field and the broader societal discourses of which they are a part influence each other in many different ways. In particular, societal-level discourses facilitate and constrain, produce and are produced by, activities at the level of the particular institutional field.

In summary, discursive activity is a form of political activity because of the way in which it changes understandings of a social situation which, in turn, shape particular experiences and invoke certain practices. Discursive activity may result in changes in concepts, in different concepts being applied to objects, and in the emergence of different subject positions with different voices. The discursive strategies of an individual actor do not operate in a vacuum, however, nor are the possible configurations of concepts, objects and subject positions limitless or subject to infinite manipulation. They are embedded in a rich context of meanings and understandings that emerge from ongoing struggles both within the institutional field and at a societal level. Consequently, if we are to understand discursive activity we must examine not just the strategies used by actors in institutional field, but also the broader context of relevant discourses that operate at a societal level, and the links between the two.

\section{The Canadian Refugee System ${ }^{1}$}

Canada is a signatory of the 1951 Geneva Convention and the 1967 Protocol Relating to the Status of Refugees which define the concept of a refugee. As a result, an institutional field has emerged which encompasses the formation and implementation of policies and practices that relate to the rights of individuals to claim asylum, the procedures whereby claimants are determined to be refugees, and the support provided to them (Hardy 1994a). ${ }^{2}$ Canadian determination procedures are the result of Bill C-55 — The Refugee Reform Bill ${ }^{3}$ — which was originally introduced in Parliament in 1987, and implemented in January 1989. The Immigration and Refugee Board, which consists of around 250 members appointed by Cabinet and supported by 700 staff, determine whether individuals qualify for asylum. Refugee claimants have the right to an oral hearing by this Board and are entitled to free legal representation. Of the cases that were processed during the years 1989-91, 70 percent of claimants were determined to be refugees.

A large number of nongovernment organizations (NGOs) operate in the Canadian system. They are typically provincially based and provide a combination of protection, advocacy and settlement services to refugees. Over one hundred such NGOs are members of the national umbrella body, the Canadian Council for Refugees. In addition, around ten percent of the Council's membership is comprised of refugee organizations — small, ethnic-based organizations that traditionally advocate on behalf of, and provide services to, particular groups of refugees.

The Canadian refugee system can be conceptualized as an institutional field that includes a number of actors who together shape the concept of a refugee, as well as determine which particular individuals are refugees. These actors can, for analytic purposes, usefully be divided into government, nongovernment and refugee organizations. These three broad categories represent three primary subject positions that exist in the refugee system.

\section{Discursive Struggle in the Canadian Refugee System}

The refugee system is marked by considerable discursive struggle around a number of key concepts which help to constitute a framework within which different objects are produced. 
In this section, we first examine the struggle between the concepts of human rights — which evokes a refugee who warrants protection - and sovereignty - which suggests large numbers of 'bogus' refugees or 'economic' migrants whose access to the country must be controlled. We then explore the conflict between paternalism - which leads to a view of refugees in need of care - and empowerment — which promotes refugees who are self-reliant and independent (also see Hardy 1994a; Phillips and Hardy 1997).

\section{Human Rights and Sovereignty}

The struggle between human rights and sovereignty manifests itself in the conflict between those who advocate greater and easier access to asylum in Canada and those who insist that controls are necessary to restrict the numbers of refugee claimants arriving in Canada. For example, the introduction of Bill C-55 was justified in terms of both humanitarian goals and the increased control of arrivals. It was tabled, according to the Minister of Immigration, to provide an oral hearing for all refugees, to offer quicker determination, and to 'curb abuse'. The Immigration and Refugee Board described the purpose of the new procedures as restoring 'national and international credibility to the manner in which Canada treats people claiming to be Convention refugees' (Immigration and Refugee Board 1989: 10). The 1990 Auditor General's Report, on the other hand, advocated their deterrent effect, considered necessary to address the increasing number of claims 'made by economic migrants who claimed refugee status under false pretences’ (p. 347).

Another example of the struggle between human rights and sovereignty concerns another piece of legislation — Bill C-84. After the introduction of Bill C-55 in May 1987, 174 Sikh asylum seekers arrived by boat in Nova Scotia in July. They were found to have set sail, not from India, but from the Netherlands. Parliament was recalled and emergency measures in the form of Bill C-84 — The Refugee Deterrent and Detention Bill — was introduced to prevent such an event from happening again. ${ }^{4}$ It increased penalties for airlines that brought in undocumented individuals, allowed Canadian officials to detain refugees and turn back boats, and introduced other means to deter asylum seekers from seeking refuge in Canada. For some politicians and civil servants, this emphasis on the control of borders was at the unacceptable expense of refugee rights. For example, the Senate made a number of amendments to remove some of the more drastic measures and twice sent the Bill back to the House of Commons before it was given royal assent the following year (Matas 1989).

A third example of this struggle can be seen in the 'third safe country' rule. The idea behind Bill-55 was the return of claimants to any 'safe' country they had passed through en route to Canada to reduce the number of claimants seeking asylum from Canada. The legislation allowed for the creation of a list of safe countries by Cabinet but the list was never drawn up, partly because of the actions of the USA, which routinely returned refugee claimants to Central American countries which Canada considered unsafe ${ }^{5}$ :

Given that the safe country concept had been so central to the bill and defended vigorously by the government, the fact that the system came into force without a safe country list may seem surprising. In reality it reflects the very serious political difficulty that the list presented to Cabinet, particularly in regard to the United States. To have put that country on the list as safe without an exception for claimants from certain Central American countries would have been to fly in the face of common knowledge and experience [that the US returned such claimants to their countries of persecution]. Yet making such an exception appears to be a 
step that Cabinet has not been politically prepared to take to date (Young 1989:

15).

The unwillingness to impose the third safe country rule meant that the human rights (of Central American refugees) were protected even though it meant that the numbers of refugee claimants gaining access to the Canadian determination system would be far greater.

We can see, then, evidence of a struggle in the Canadian refugee system between the concept of human rights — the promotion of 'deserving' refugees who warrant access to Canada — and sovereignty — which weeds out 'economic' migrants, preventing them from securing access. Consider the following statement made by an immigration official:

It is frustrating for the staff. Even of those allowed to stay, some of them are undoubtedly bogus. They are taking advantage of a system that is cumbersome. There are many delays with repeat appeals. There are three or four opportunities for a review. Even when the system works the way it's meant to work, there's abuse. People feel that genuine refugees don't get the chance to get here while many of those who do are economic migrants.

Yet this same official goes on to say:

But we have 250,000 immigrants - the bulk of people are coming through normal channels. We are not overwhelmed by refugees.... We're so Canadian we invite people in but the potential of large-scale abuse is there. Look at the unprecedented return of the boatloads of Haitians by the US. We don't have a mechanism to turn them back. We wouldn't turn away boatloads of people. It's un-Canadian and that's good... Where the decision has so much impact on human life, when you can send people back into danger that's when the benefit of the doubt is so important. Also one more doesn't matter. In fact, another 10,000 don't matter.

In other words, this official experiences the same struggle that pervades the system as a whole.

\section{Paternalism and Empowerment}

Another struggle arises around the contradictory views regarding the self-reliance of refugees, which emanates from tensions between paternalism and empowerment. The concept of paternalism promotes a stereotypical view of refugees as helpless, defenceless individuals in desperate need of protection and care.

Refugees are a marginalized population. They have left their own state and are now residents of a different state, of which they are not citizens. Their status is regulated by international agreements, but there is no way for the international community to enforce these agreements, much less for the individual refugee, who may not even be aware of their existence, to insist on his or her rights. The situation may change from one moment to the next if there is a shift in the way the war in the refugees' country is going, if the government of the host country changes, or even if that government merely decides to change its refugee policy. The refugee may find himself the subject of multiple power-holders who are at odds with one another: the UN agencies and their local representatives, under orders from Geneva; the representatives of the central government of the host country; the representatives of the local or regional administration, which may be pursuing policies significantly at variance to those of the central government; the representatives of political parties or movements of the refugee's own country or political movement (Benard 1986: 627). 
This identity, often seen on television in the aftermath of war or following mass displacements of people and associated with the large numbers of refugees huddled in inadequate refugee camps, is born of discourses common in development work.

[R]efugees are assumed to be completely helpless and crying out for any assistance that can be given to them. A condition such as this is seen to require direct action and intervention, independent of the participation of, or consultation with, the refugees themselves.... [which] deprives refugees of the use of their own coping mechanisms which are so important to re-establish identity, self-esteem and dignity (Needham 1994: 17).

This view remains even after refugees have arrived in 'developed' countries like Canada, where they are continue to be relegated to a secondary role compared to the members of established NGOs.

The refugee groups come to the Canadian Council for Refugees to educate the rest of the constancy and to add colour to a particular claim. They aren't decisionmakers, they play no intellectual role, nor any political leadership role (member of the Canadian Council for Refugees).

Traditional models of social work (see Hasenfeld and Chesler 1983) place the refugee in a subordinate role to professionals who are responsible for providing the services and protection they 'need'.

There are, of course, refugees working [in the settlement agencies] but it is mainly social workers ... [who] see the refugees in terms of casework. Very few of them use other models. Traditional views are also imposed on them from the government (member of the Canadian Council for Refugees).

The concept of empowerment (Simon 1990), on the other hand, projects a view of a selfreliant, autonomous, independent refugee, capable of making decisions that affect his or her life. We need to get them [refugees] on the Canadian Council for Refugees — that would be empowerment... Once there, they will change things on their own behalf. They will have to carve a niche for themselves (refugee).

Such moves towards empowerment to increase the influence of refugee organizations in the NGO community have, however, led to conflict.

When our [refugee-led] organization started, there was a lot of tension with other service providers especially the churches. The Canadian tradition has been one of welcoming refugees for a long time, especially through the churches. Some of us didn't want to work the churches ... Some of the churches have been very bitter about that (refugee).

Thus there is an inevitable tension between paternalism and empowerment as these concepts apply to refugees.

It depends on whether you see refugees as a group that needs help or a political community with rights and interests. If the extent of your analysis is that refugees need help and then refugees start organizing then maybe your response is going to be: what's going on.... To [some organizations], refugees are not a client group they are an interest group but that is not always the case (member of the Canadian Council for Refugees).

In summary, then, the institutional field that comprises the Canadian refugee system encompasses two important struggles that pit discourses of human rights against sovereignty, and paternalism against empowerment. This struggle has important implications for refugee identity: 
as genuine and deserving; as fraudulent and abusive; as needy and helpless; as autonomous and independent.

\section{Strategies in the Struggle}

While the discursive struggles described above are complex and involve many crosscutting currents, they are not completely random. The main actors, or subject positions, in the refugee system have a stake in the struggle (Phillips and Hardy 1997). As we explain in this section, the government is in the 'business' of determination, which is enhanced by juxtaposing deserving refugees against 'economic migrants'; the latter to be unmasked by the determination system. White-led NGOs that speak and advocate on behalf of refugees are in the 'business' of service provision, which is enhanced by refugees as needy 'clients' to whom professionals can dispense services. Refugee community organizations are in the 'business' of self-help, which is enhanced by refugees as fully functioning and equal 'members' of society.

The government is responsible for developing and implementing the determination procedures, as well as for the heavy investment in setting up and financing the Immigration and Refugee Board. For this investment to be worthwhile, and for government actions to be condoned and supported by the electorate, a significant number of refugee claims must be fraudulent. If refugee claimants are all genuine and deserving of protection, there is no need for taxpayers' money to be spent on an expensive determination system and there is little justification for subjecting asylum-seekers to delay and uncertainty. In contrast, the position of NGOs and refugee organizations that provide support to refugees is jeopardized if large numbers of refugees are fraudulent — such individuals are neither deserving of protection nor eligible for support to settle in their adopted country.

Thus the struggle between human rights and sovereignty traditionally pits government against NGOs and refugee organizations. For the former, refugees provoke 'a reaction dominated by the notion of state security and the control of immigration, to NGOs it invites a notion of democratic rights and solidarity’ (Rudge 1989: 28-9). ). These conflicting positions are illustrated in the following two statements.

There was the natural tendency of the government and especially the [Immigration] department to have control over its borders. That is after all what we pay them to do, versus the sense of many of the NGOs that we should throw open the door to anyone who said they needed refuge and in some cases, to anyone who wanted to come regardless of what their circumstances were. Those two value systems are not compatible. There's not much room for compromise between those who want to let everybody in and those who want to control our borders (civil servant).

We may have had some conversations [with the bureaucrats] but we were at cross-purposes and our agendas were totally at odds. Their agenda was a control agenda and ours was a protection agenda and we didn't even accept the government agenda as a legitimate concern. Well, maybe that's going too far the concern was legitimate but they were taking it to extremes. It became a public battle rather than a conversation (member of Canadian Council for Refugees).

The struggle between paternalism and empowerment, on the other hand, tends to place

NGOs and refugees in conflict. The role of NGOs in speaking on behalf of refugees is undermined if refugees are capable of representing their own rights. In this case, it would be more effective to channel resources and policy discussions directly towards the refugee groups, cutting NGOs out of the loop. Thus NGOs have a stake in needy, helpless refugees. For refugees 
to gain a voice in the refugee system, they must be genuine — deserving of protection — but not in such need of protection and help that they are unable to stand up for themselves. So, they must also be autonomous and self-reliant.

I realized that what we needed to do is organize because almost all the refugee communities were disorganized. When the government turned the heat on, they got scared and ran to the NGOs for help. But I thought that was not the solution. It was too paternalistic and the NGOs were part of the system. They can help [but only] up to a point. They are trying to challenge the government on issues they think are inhuman but they only way they know if a situation is inhuman is from the refugees themselves. So I thought these groups should organize, to do the research and get the documentation, and convince the government or whoever does the refugees determination of the real situation which is driving people to this country. That way they couldn't accuse us of being bogus or queue-jumpers (refugee).

In summary, underlying the social reality of the Canadian refugee system is an intense discursive struggle to determine the nature of concepts and how they are applied to objects in order to change the accomplishment of social relationships. This leads to an ambiguous and contested set of discursive structures full of contradiction and subject to continuous negotiations as to their meaning and application. Consequently, members of the institutional field government, NGOs and refugees - engage in discursive activity in their attempts to influence the outcome of these struggles. This activity is affected by broader discourses that impinge on refugee concerns such as immigration, race, employment, patriotism, religion, etc. In the following section, we focus on the example of immigration discourse to explore the broader context in which refugees are constituted.

\section{Societal-Level Discourse and the Constitution of Refugees}

The task of exploring the societal level discourse is problematic. While it is practical to track the specific discursive activities of members of a particular institutional field (e.g., Phillips and Hardy 1997), it is far more difficult to identify and examine a discourse that operates at a societal level (van Dijk 1997c). As Parker (1992) has pointed out, we do not find discourses in their entirety, but only clues in particular texts. Accordingly, our study relies on one form of text - cartoons - to represent the broader discourse of immigration and to examine how it constitutes refugees and other objects.

We use editorial cartoons as an indicator of the broader societal discourse on immigration for several reasons. First, cartoons have been found to be particularly helpful device in research - they have been used to explore a variety of concepts and objects, including the economy (Emmison 1986), bi-lingualism in Quebec (Morris 1991), political regimes (Press 1981), and organizations (Collinson 1988; Filby and Wilmott 1988; Hatch 1997; Rodrigues and Collinson 1995). Second, cartoons are publicly available and relatively easy to gather: it is practical to collect all of the cartoons published in major Canadian newspapers over a particular time period. Third, cartoons are relatively self-contained texts that portray concise representations of alternative discursive positions. They can be analyzed and discussed in a relatively limited space, and examples can be shown.

Fourth, political cartoons range broadly across topics and include many different political perspectives and points of view, thus providing a broad sampling of the discourse around immigration. They express very different views: some observers argue they are a democratic 
check on the abuse of executive power (Press 1981); while others see them as jesters of the bourgeoisie (Morris 1989). Similarly, humour has been seen both as a conservative (Mulkay 1988) and a liberating (Douglas 1975) force in society; as well as a means of domination (see Rodrigues and Collinson 1995) and a form of resistance (Roy 1958) in organizational settings. As a result, cartoons often bring opposing discourses together and speak from multiple subject positions, which is particularly useful in our attempt to examine the role of discourse in the multifaceted struggle characterizing the Canadian refugee system.

Finally, the cartoonist expresses the interests and views of a social group (Press 1981) by conveying a particular way of looking at people and settings (Gombrich 1978). Political cartoons 'are a metalanguage for discourse about the social order. They create imaginary worlds which allow a fresh perspective on the present world by inverting certain of its features' (Morris 1991: 225). Cartoons set up a mini-narrative which highlights certain regularities and features of the object of the caricature and suppresses others in order to juxtapose order and disorder, or sense and nonsense (Morris 1989; 1991; also see Mulkay 1988; Hatch and Ehrlich 1993; Weick and Westley 1996 on humour). In so doing, they provide a discursive space 'outside' the discourse in question, whose assumptions the cartoonist seeks to expose, and which can be discerned by examination of the drawings (Morris 1991).

To examine the interplay between institutional field-level discourse and the broader immigration discourse, we examined the 127 cartoons that we were able to track in Canadian newspapers on refugees and immigration during the years 1987, 1988 and 1989. We chose to study these particular years because a major piece of new legislation concerning refugee determination (Bill C-55) as well as emergency legislation (Bill C-84) were passing through the Houses of Parliament during this period. As a result, we expected to find a relatively large number of editorial cartoons that would reflect not only on refugees, but also immigrants generally, the immigration system, the government and the public. We do not analyze in detail what the messages of these cartoons signify; rather we consider the assumptions they reflect (see Emmison 1986).

As a first step, we analyzed the 127 cartoons to see exactly which objects were represented in them. We found that each cartoon represented one or more of four objects: the refugee, the government, the immigration system and the public. In a second step, we examined how each cartoon constituted these objects. We found that the objects were constituted according to one or more of 18 themes, which are listed in Table 1 . We found that refugees were constituted as frauds (see example in Figure 1), victims (see Figure 2), both victims and frauds, and as privileged in comparison to other immigrants. The government was constituted as cruel, corrupt, incompetent, and subject to conflicting tensions. The immigration system was constituted as inconsistent; inadequate; too tough (Figure 3); too lenient (Figure 4); too slow; gullible; and honourable. The public was portrayed as requiring protection and being opposed to refugees. Finally, we classified 22 incidences of 'inversion' where the cartoon used refugees to comment on other issues, such as the rights of first nations or government corruption.

\section{- Table 1 near here -}

We then noted how many times the objects were constituted in these various ways, as indicated by the numbers in Table 1 . We found the following: refugees were most commonly constructed as fraudulent; the second most common construction was as both victims and frauds. Less often, refugees were portrayed as simply victims. The government was constructed most commonly as cruel; the number of incidences of corruption and incompetence were similar. The immigration system was primarily portrayed as being inconsistent, in terms of both being 
presented as inconsistent and being seen as too lenient nearly as often as it was too tough. It was also seen as inadequate to deal with the large numbers of refugees entering Canada. The public, which was represented less often, was seen primarily as being in need of protection.

By using cartoons as a representation of immigration discourse, we see how it helps to produce not only refugees, but also other objects such as the government, the immigration system, and the public. This analysis allows us to consider the relationship between this broader discourse and the discursive activity within the particular institutional field - the Canadian refugee system — discussed in the previous section.

\section{Societal-Level Discourses as a Resource for Institutional Fields}

We suggest that broader societal discourses mirror and add to the discursive struggles within an institutional field by constraining and facilitating the discursive activities of the individual actors. In this section, we examine how immigration discourse, as represented in the cartoons, provides a resource for the discursive activities of actors in the Canadian refugee system (also see Cohen 1994; van Dijk, et al. 1997 on immigration discourse).

If refugees are genuine, needy and helpless, the government's authority and right to control determination procedures becomes difficult to justify. As a result, it is in the government's interests to argue that refugees are either fraudulent or a threat if its investment and role in the determination system is to be supported. (For details on such strategies in the context of the UK system, see Phillips and Hardy 1997.) The cartoons reveal that societal immigration discourses can be used to support both these positions. Our analysis shows that the refugees are primarily portrayed as frauds and, in many cases, even where legitimate refugees appear in cartoons, they are juxtaposed against illegitimate ones. In addition, the system is often shown to be inadequate in safeguarding a public that is primarily in need of protection. In other words, within the broader immigration discourse are constructions of not only refugees, but also an immigration system and a public, which support and reinforce government control over immigration.

NGOs engage in discursive activity to challenge the government assumptions by portraying refugees as genuine, but also needy and helpless. Such actions reinforce their access to resources, their right to represent refugees, and to provide them with services. The NGOs also have recourse to discursive resources to support their position i.e., the portrayal of the government as cruel, corrupt and incompetent; and a system that is inconsistent and often too tough. If the immigration system and the government cannot be relied upon to protect refugees, then the need for NGOs becomes clear. So, while the refugee as victim is not a common portrayal on which NGOs can draw, the way in which the government and the immigration system is represented does provide them with discursive ammunition.

In the case above, the NGOs' interest in the genuine refugee converges with the interests of refugee organizations, which are also threatened by the government's invocation of a fraudulent or threatening refugee. However, the portrayal of refugee as victim — as needy and helpless - undermines refugee organizations that wish to take control of refugee issues. These refugee organizations have an interest in invoking refugees as autonomous and independent. But, when we look at the cartoons, there is nothing that represents the refugee as autonomous, empowered, independent human being, which means that refugees must explore other discourses to find the discursive resources they require.

In summary, the analysis of the cartoons suggests that the ability of actors to develop effective discursive strategies in an institutional field is influenced by the availability of 
discursive resources not only within the field but also at a societal level. The immigration discourse provided resources on which both government and NGOs could draw to support their position. Refugees, on the other hand, faced a more difficult time in constituting themselves as autonomous and independent members of society, at least in part, because of a lack of discursive resources at the societal level.

\section{Implications and Conclusions}

The general framework that we have developed in this paper focuses attention on the discursive activity that occurs as organizations struggle to affect the development of institutional fields. We have attempted to contexualize discursive activity and to mediate 'the connection between language and social context' and facilitate 'more satisfactory bridging of the gap between texts and contexts' (Fairclough 1995: 189) by linking discursive activities that occur at the level of the institutional field with broader societal-level discourses.

It is this broader account of discourse in society and culture which may be seen as the culmination of discourse studies. In such a vastly complex framework we are able to go beyond the mere study of discursive sentence combinations, coherence, speech acts, conversational turns or topic change.... Indeed if we want to explain what discourse is all about, it would be insufficient to merely analyze its internal structures, the actions being accomplished, or the cognitive operations involved in language use. We need to account for the fact that discourse as social action is being engaged in within a framework of understanding, communication and interaction which is in turn part of broader sociocultural structures and processes (van Dijk 1997c: 21)

Accordingly, we can see that the strategies used by the government to promote the concept of sovereignty were reinforced by immigration discourses that portrayed refugees as frauds, the immigration system as inadequate and the public as requiring protection. The strategies used by NGOs to advance human rights and paternalism could draw on depictions of the government as incompetent, corrupt and cruel, and portraits of the immigration system as too slow, too tough and inconsistent. Refugee strategies to advocate empowerment were hampered, however, in so far as the immigration discourse was concerned since it provided no compatible images (table 2). Consequently, we might expect to see refugees attempt to draw on related discourses, such as community empowerment, race, and political correctness in order to find a subject position - or voice - from which to influence the institutional field.

\section{- Table 2 near here -}

We can identify a number of areas where research might be usefully directed to increase our understanding of these complex processes. First, the role played by discursive activity in processes of institutionalization requires further theoretical development and empirical investigation. Discourse analysis provides a theoretical approach to understanding the processes of institutionalization, whereby institutional fields change. By focusing on the production and dissemination of texts and how these texts produce concepts and objects of various kinds, we can understand how institutionalized practices and understandings come into being through the purposeful activities of field members. Rather than an abstract process of institutionalization that affects actors 'behind their backs' (Powell and DiMaggio 1991), we can focus more directly on how the strategies of actors affect institutionalization.

Second, we need to understand much more clearly how societal-level discourses affect 
the dynamics of institutional fields. It is clear that certain actors are advantaged by the existence of concepts that they can draw into service as they implement their strategies of institutional entrepreneurship (Powell and DiMaggio 1991). For example, in another study, we examined how changes in societal understandings of killer whales supported the development of a commercially viable whale watching industry on Canada's western coast (Lawrence andPhillips 1997). But the exact nature of the relation between these discursive resources and the ability of actors to produce successful discursive strategies remains unclear.

Third, the development of effective discursive strategies is a question of both practical and academic significance. It is clear that changes can occur which allow less powerful actors in an institutional field to have a discursive impact. For example, environmentalists faced a similar position to refugees when they lacked the concepts necessary to construct the threat of environmental degradation. Over time, however, concepts like 'global warming', 'endangered species', and 'sustainable development' have become commonplace at the societal level. These concepts are now easily accessed at the level of the institutional field by environmental groups, corporations, governments, and other actors as they struggle to change or maintain the institutionalized structures that characterize the field. Exactly how these changes occur and what leads to success is not, however, well understood and research might usefully be targeted at exploring these processes.

Finally, more research is also needed to explore how activity in the institutional field influences societal-level discourses. We found 22 cases where the concept of a refugee was used to represent other objects - members of Canada's First Nations, political corruption, Quebec separation and the environment (table 1). So, we can see that discourse around refugees appears interdiscursively in a range of other discourses. So, if refugees start to assert themselves in the Canadian refugee system, we might expect to see modifications to a number of societal-level discourses. This has happened in the case of members of Canada's First Nations, who are now often portrayed as self-sufficient, self-possessed, savvy aboriginals as a result of discursive activities in specific institutional fields, such as the Canadian constitution, energy resources and land claims. Moreover, their juxtaposition against defenceless refugees in these inverted cartoons clearly demonstrates their acquisition of power. The existence of patterns of interdiscursivity shows, then, that successful challenges to existing discourses can have important, and unexpected, ramifications across society. 
Table 1: Themes of Analysis

\begin{tabular}{|c|c|c|c|}
\hline Actor & Theme & \# & Definition \\
\hline \multirow[t]{4}{*}{ Refugee } & Victim & 11 & $\begin{array}{l}\text { Those presenting themselves as refugees are at } \\
\text { risk from persecution and warrant protection }\end{array}$ \\
\hline & Fraud & 22 & $\begin{array}{l}\text { Those presenting themselves as refugees are in no } \\
\text { danger }\end{array}$ \\
\hline & Both & 13 & $\begin{array}{l}\text { Those presenting themselves as refugees may be } \\
\text { either of the above }\end{array}$ \\
\hline & Priviledged & 2 & $\begin{array}{l}\text { Those presenting themselves as refugees gain } \\
\text { quicker access to Canada than other immigrants }\end{array}$ \\
\hline \multirow[t]{4}{*}{ Government } & Incompetent & 8 & $\begin{array}{l}\text { The government is unable to administer the } \\
\text { system effectively }\end{array}$ \\
\hline & Corrupt & 9 & $\begin{array}{l}\text { Individuals in the government allows entry to } \\
\text { Canada based on personal reasons }\end{array}$ \\
\hline & Cruel & 13 & $\begin{array}{l}\text { The government is unwilling to take responsiblity } \\
\text { for refugees }\end{array}$ \\
\hline & Under tension & 6 & $\begin{array}{l}\text { The government is subject to contradictory and } \\
\text { unresolvable tensions regarding their } \\
\text { responsiblity to refugees and the public }\end{array}$ \\
\hline \multirow[t]{7}{*}{$\begin{array}{l}\text { Immigration } \\
\text { System }\end{array}$} & Honourable & 1 & $\begin{array}{l}\text { The determination system carries out its } \\
\text { responsibilities towards refugees }\end{array}$ \\
\hline & Too slow & 7 & $\begin{array}{l}\text { The determination system takes too long to render } \\
\text { decisions }\end{array}$ \\
\hline & Too tough & 12 & $\begin{array}{l}\text { The determination system keeps out people who } \\
\text { should be allowed in to Canada }\end{array}$ \\
\hline & Too lenient & 10 & $\begin{array}{l}\text { The determination system lets people in who } \\
\text { should be kept out of Canada }\end{array}$ \\
\hline & Inconsistent & 23 & $\begin{array}{l}\text { Certain groups, such as illegal immigrants, } \\
\text { fraudulent refugees or individuals with political } \\
\text { connections, are treated preferentially }\end{array}$ \\
\hline & Inadequate & 17 & $\begin{array}{l}\text { The determination system is unable to prevent } \\
\text { large numbers of refugees entering Canada }\end{array}$ \\
\hline & Gullible & 7 & $\begin{array}{l}\text { Officials are unable to distinguish between } \\
\text { genuine and fraudulent refugees }\end{array}$ \\
\hline \multirow[t]{3}{*}{ Public } & Opposed & 4 & $\begin{array}{l}\text { The public is opposed to refugees entering } \\
\text { Canada }\end{array}$ \\
\hline & Supportive & 0 & $\begin{array}{l}\text { The public is supportive of refugees entering } \\
\text { Canada }\end{array}$ \\
\hline & Requiring protection & 8 & $\begin{array}{l}\text { The public requires protection from large } \\
\text { numbers of refugees entering Canada }\end{array}$ \\
\hline Inversion & $\begin{array}{l}\text { Concept of refugee } \\
\text { constructs another issue }\end{array}$ & 22 & $\begin{array}{l}\text { First Nations (9); political corruption (9); Quebec } \\
\text { separation (3); environment (1) }\end{array}$ \\
\hline
\end{tabular}


Table 2: Discursive Resources

\begin{tabular}{|l|l|l|}
\hline & $\begin{array}{l}\text { Institutional field: } \\
\text { strategies }\end{array}$ & Societal discourse: resources \\
\hline Government & $\begin{array}{l}\text { Sovereignty } \\
\text { Paternalism }\end{array}$ & $\begin{array}{l}\text { Refugee: fraud } \\
\text { Immigration system: inadequate } \\
\text { Public: requiring protection }\end{array}$ \\
\hline NGOs & $\begin{array}{l}\text { Human Rights } \\
\text { Paternalism }\end{array}$ & $\begin{array}{l}\text { Refugee: victim } \\
\text { Government: incompetent; corrupt; cruel } \\
\text { Immigration system: too slow, too tough; } \\
\text { inconsistent }\end{array}$ \\
\hline Refugees & $\begin{array}{l}\text { Human Rights } \\
\text { Empowerment }\end{array}$ & ?? \\
\hline
\end{tabular}




\section{Notes}

${ }^{1}$ This study is part of a larger study comparing refugee systems in Canada, the UK and Denmark. Data was collected through interviews with members of government and nongovernment organizations, as well as refugees. The interviews were semi-structured, between one and three hours long. Quotations from these interviews appear in this paper. In addition, other documentation, such as Hansard, newspaper reports, government reports, etc. was collected and analyzed.

${ }^{2}$ The terminology used here is as follows: an asylum-seeker or refugee claimant is an individual seeking asylum; refugee refers to an individual granted asylum whether as a refugee or some other category. Determination refers to the process whereby an individual's status is ascertained. Nongovernment organizations and lawyers who represent and advise claimants concerning their rights in this process are known as protection agencies. Settlement refers to the services provided to refugees to help them settle in their new country. It includes training, housing and other support services. Advocacy relates to the political activities of the nongovernment sector.

${ }^{3}$ At that time there were 85,000 claims waiting in a backlog from as early as 1986. The government also introduced additional, streamlined procedures for these cases in an attempt to clear this backlog .

${ }^{4}$ It is worth noting that a similar landing a year earlier evoked a very different response. In August 1986, a boat containing 155 Tamils from Sri Lanka arrived off the shores of Newfoundland. 'The Tamils were received with open arms and given Minister's Permits despite the fact they lied [about their embarkation point], without any investigation of whether they were refugees ... The Sikhs were not given Minister's Permits... The Sikhs were treated as badly as the Tamils had been treated generously. They were initially detained, denied access to counsel and not brought before an adjudicator within the time period required by law.' (Matas, 1989: 94/96).

${ }^{5}$ A US District Court hearing in 1988 (Orantes Hernandes vs. Meese) that found that the US was unsafe for Salvadoran refugees. Also see Allen and Michnick, 1987. 


\section{References}

Allen, Helen S. and Karen Michnick

1987 'Refugee measures imperil Canada's humanitarian image’. Perception, 10: 32-34

Althusser, L.

1971 Lenin and philosophy and other essays. London: New Left Books.

Auditor General

1990 Report to the House of Commons. Ottawa: Minister of Supply and Services.

Benard, Chester

1986 'Politics and the refugee experience'. Political Science Quarterly, 101(4): 617-636.

Boje, David M.

1995 'Stories of the storytelling organization: A postmodern analysis of Disney as "TamaraLand”'. Academy of Management Journal, (4): 997-1035.

Clegg, Stewart

1989 Frameworks of power. London: Sage.

Cohen, Robert

1994 Frontiers of identity: The British and the others. London: Longman.

Collinson, David

1988 'Engineering humour: Maculinity, joking and conflict in shop-floor relations'. Organization Studies, 9: 181-199.

Condor, Susan and Charles Antaki

1997 'Social cognition and discourse'. in Discourse as structure and process. T.A. van Dijk (ed.), London: Sage.

Di Maggio, Paul

1988 'Interest and agency in institutional theory'. in Institutional patterns and organizations. Cambridge, L. Zucker (ed.), Mass: Ballinger.

DiMaggio, Paul J. and Walter W. Powell

1983 'The iron cage revisited: Institutional isomorphism and collective rationality in organizational fields'. American Sociological Review, 48: 147-160.

Douglas, Mary

1975 Implicit messages. London: Routledge.

Emmison, Mark

1986 'Visualizing the economy: Fetishism and the legitimation of economic life'. Theory, Culture and Society, 3(2): 81-96. 
Fairclough, Norman

1992 Discourse and social change. Cambridge: Polity Press.

Fairclough, Norman

1995 Critical discourse analysis. Harlow, Longman.

Fairclough, Norman and Wodak, Ruth

1997 'Critical discourse analysis'. in Discourse as social interaction, T.A. van Dijk (ed.), 258284. London: Sage.

Ford, Jeffrey D. and Laurie W. Ford

1996 'The role of conversations in producing intentional change in organizations'. Academy of Management Review, (3): 541-570.

Foucault, Michel

1972 The archeology of knowledge. London: Routledge.

Gardiner, Michael

1992 The dialogics of critique. London: Routledge.

Garsten, Christina and Christopher Grey

1997 'How to become oneself: Discourses of subjectivity in post-bureaucratic organizations'. Organization, (2): 211-228.

Gergen, Kenneth

1991 The saturated self: dilemmas of identity in contemporary life. New York: Basic Books.

Giddens, Anthony

1984 The constitution of society. Berkeley: University of California Press.

Gombrich, Ernest Hans

1978 Meditations on a hobby horse. New York: Phaidon.

Gray, Barbara

1989 Collaborating. San Francisco: Jossey-Bass.

Hamilton, Peter M.

1997 'Rhetorical discourse of local pay’. Organization, (2): 229-254.

Hardy, Cynthia

1994a 'Underorganized interorganization domains: The case of refugee systems,' Journal of Applied Behavioural Science, 30(3): 278-296.

Hardy, Cynthia

1994b Managing strategic action: Mobilizing change. London: Sage.

Hardy, Cynthia

1997 Strategic stretch in the voluntary sector: collaboration in the West Bank and Gaza. Paper presented at the Annual Conference of the Academy of Management, Boston. 
Hardy, Cynthia and Nelson Phillips

Forthcoming 'Strategies of engagement: Lessons from the critical examination of collaboration and conflict in an interoganizational domain'. Organizational Science.

Harré, Rom

1979 Social being: A theory for social psychology. Oxford: Basil Blackwell.

Hasenfeld, Yeheskel and Mark A. Chesler

1989 'Client empowerment in the human services: Personal and professional agenda'. Journal of Applied Behavioral Science, 25: 499-521.

Hatch, Mary Jo

1997 'Irony and the social construction of contradiction in the humor of a management team'. Organization Studies, 8(3): 275-288.

Hatch, Mary Jo and Sanford B. Ehrlich,.

1993 'Spontaneous humour as an indicator of paradox and ambiguity in organizations'. Organization Studies, 14(4): 505-526.

Hinings, C.R. and Royston Greenwood

1988 'The normative prescription of organizations'. in Institutional patterns and organizations: culture and environment, L. Zucker (ed.), Cambridge, MA: Balinger, 53-70.

Huff, Anne S.

1990 'Mapping strategic thought'. in Mapping strategic thought, A. S. Huff (ed.), 11-49. New York: John Wiley and Sons.

Immigration and Refugee Board

1989 Annual report. Ottawa: Immigration and Refugee Board.

Keenoy, Tom, Cliff Oswick and David Grant

1997 'Organizational discourses: Text and context'. Organization, (2): 147-158.

Laclau, Ernesto and Chantal Mouffe

1987 Hegemony and socialist strategy: Towards a radical democratic politics. London: Verso.

Lawrence, Thomas B.

1997 Rule, rituals and resistance: Membership dynamics in institutional fields. Working paper, University of Victoria. Victoria, British Columbia.

Lawrence, Thomas and Nelson Phillips

1997 From Moby Dick to Free Willy: Societal discourse and the discursive construction of cultural industries. Paper presented at the Research Perspectives on the Management of Cultural Industries Conference, Stern School, New York University.

Litvin, Deborah

1997 'The discourse of diversity: From biology to management'. Organization, (2): 187-210.

Matas, David 
1989 Closing the doors. Toronto: Summerhill.

Mauws, Michael and Nelson Phillips

1995 'Understanding language games’. Organization Science, (3): 322-34.

Morris, Raymond N.

1991 'Cultural analysis through semiotics: Len Norris' cartoons on official bilingualism'. Canadian Review of Sociology and Anthropology, 28(2): 225-254.

Morris, Raymond N.

1989 Behind the jester's mask. Toronto: University of Toronto Press.

Mulkay, Michael

1988 On humour: Its nature and its place in modern society. Cambridge: Polity Press.

Mumby, Dennis and Cynthia Stohl

1991 'Power and discourse in Organization Studies: Absence and the dialectic of control'. Discourse and Society, (3): 313-332.

Mumby, Dennis and Robin P. Clair

1997 'Organizational discourse'. in Discourse as social interaction, T. A. van Dijk (ed.), 181205. London: Sage.

Mumby, Dennis K.

Forthcoming 'Power, politics and organizational communication: Theoretical perspectives'. in The new handbook of organizational communication. F. Jablin and L. Putnam (eds.) London: Sage.

Needham, Richard

1994 'Refugee participation', Refugee participation network \#17, August, Oxford: Refugee Studies Program.

Ochs, Elinor

1997 'Narrative'. in Discourse as structure and process. T.A. van Dijk (ed.), London: Sage.

O'Connor, Ellen S.

1995 'Paradoxes of participation: Textual analysis and organizational change'. Organization Studies, (5): 769-803.

Parker, Ian.

1992 Discourse dynamics. London: Routledge.

Phillips, Nelson

1995 'Telling organizational tales: On the role of narrative fiction in the study of organizations'. Organization Studies (4): 625-649.

Phillips, Nelson and Cynthia Hardy 
1997 'Managing multiple identity: Discourse, legitimacy and resources in the UK refugee system’. Organization, 4(2): 159-186.

Potter, Jonathan and Margaret Wetherell

1987 Discourse and social psychology: Beyond attitudes and behaviour. London: Sage.

Powell, Walter W. and Paul J. DiMaggio

1991 The new institutionalism in organizational analysis. Chicago: University of Chicago Press.

Press, Charles

1981 The political cartoon. New Brunswick, NJ: Fairleigh Dickinson University Press.

Rodrigues, Suzana B. and David L. Collinson

1995 'Having fun?' Humour as resistance in Brazil'. Organization Studies, 16(5): 739-768.

Rorty, Richard

1989 Contingency, irony, solidarity. Cambridge: Cambridge University Press.

Rorty, Richard

1991 Objectivity, relativism and truth. Cambridge: Cambridge University Press.

Roy, David

1958 'Banana time: Job satisfaction and informal interaction'. Human Organization, 18: 158168.

Rudge, Phillip

1989 'The failure of the spirit', Report of the proceedings of the international symposium on the refugee crisis: British and Canadian responses: 26-36. Oxford, UK: Refugee Studies Programme.

Scott, Walter R.

1995 Institutions and organizations. Thousand Oaks, CA: Sage.

Simon, Barbara L.

1990 'Rethinking empowerment'. Journal of Progressive Human Sciences, 1(1): 27-37.

Taylor, Charles

1985 Philosophy and the human sciences. Cambridge: Cambridge University Press.

Trist, Eric

1983 'Referent organizations and the development of interorganizational domains'. Human Relations, 36: 269-284.

van Dijk, Tuen A.

1997a Discourse as social interaction: Volume I. London: Sage.

van Dijk, Tuen A.

1997b Discourse as social interaction: Volume II. London: Sage. 
van Dijk, Tuen A.

1997c 'The study of discourse'. in Discourse as Social Interaction, T.A. van Dijk (ed.), 1-34. London: Sage.

van Dijk, Tuen A., Ting-Toomey, Stella, Smitherman, Geneva and Troutman, Denise

1997 'Discourse, ethnicity, culture and racism'. in Discourse as Social Interaction. T.A. van Dijk (ed.) London: Sage.

Warren, Robert, Steve Rose and Ann Bergunder

1974 The Structure of Urban Reform. Lexington, MA: DC Heath.

Watson, Tony J.

1995 'Rhetoric, discourse and argument in organizational sense making: A reflexive tale'. Organization Studies, 16(5): 805-821.

Weick, Karl E. and Frances Westley

1996 'Organizational learning: Affirming an oxymoron'. in Handbook of Organization Studies, S. R. Clegg, C. Hardy and W. Nord (eds.), 440-458. London, Sage.

Whittington, Richard

1992 'Putting Giddens into action: Social systems and managerial agency'. Journal of Management Studies, 29(6), 693-712.

Young, Margaret

1989 Canada's refugee determination system. Ottawa: Library of Parliament, Law and Government Division. (revised 1990). 


\section{University Library}

\section{- M M N E R VA A gateway to Melbourne's research publications}

Minerva Access is the Institutional Repository of The University of Melbourne

Author/s:

Hardy, C;Phillips, N

Title:

No joking matter: Discursive struggle in the Canadian refugee system

Date:

1999-01-01

Citation:

Hardy, C. \& Phillips, N. (1999). No joking matter: Discursive struggle in the Canadian refugee system. ORGANIZATION STUDIES, 20 (1), pp.1-24. https:// doi.org/10.1177/0170840699201001.

Persistent Link:

http://hdl.handle.net/11343/116088 